\title{
SCLERODERMA AS A POSSIBLE MANIFESTATION OF CHRONIC ARSENIC POISONING*
}

\author{
SAMUEL AYRES, JR., M.D. \\ LOS ANGELES
}

In three consecutive cases of diffuse scleroderma seen at the Massachusetts General Hospital within the past six months, the urine has given positive tests for arsenic. One patient, a storekeeper, had kept powdered arsenate of lead under her counter for over four years to kill mice; another had handled glazed paper in a paper box factory for ten years; the third had been exposed to the use of insecticides about the house for a number of years, but so far as could be ascertained, this occurred after the onset of the scleroderma. Further investigation into the records of two other patients, who had died, showed that they had probably been exposed to arsenic. All five of these cases were examples of diffuse scleroderma with brown pigmentation, and the condition of the three patients whom I saw personally and whose urine was positive for arsenic began with sclerodactylia, that being at present the most noticeable and most annoying symptom. Letters were sent to all former patients with undisputed scleroderma of whom we have records, nine in all, but no replies have been received.

Only one case of localized scleroderma or morphea has been studied from this angle. The patient, E. M. (O. P. D. 416812), a young woman in her twenties, had for many years been exposed to arsenic in the form of arsenical sprays in a large garden at home and in her capacity as director of school gardens. Within the past six months there had developed a saber-like, white, depressed firm lesion in the middle of the forehead extending from above the hair line, ending in a point just above the bridge of the nose, and surrounded by pale brown pigmentation. There were no subjective or constitutional symptoms. The urine gave a positive test for arsenic.

Were it not for the fact that scleroderma is such a rare disease, this paper would not be offered for publication until more cases could be analyzed; but it seems desirable to make public the facts so that they may be corroborated or refuted by as many observations as possible. It is not intended here, to urge a connection between scleroderma and arsenic poisoning, but merely to point out the possibility. The original suggestion was offered by Dr. William H. Smith of this hospital in the discussion of Case 1.

\footnotetext{
* From the Department of Dermatology, Massachusetts General Hospital, Boston.
} 


\section{REPORT OF CASES}

CASE 1.-History-West Medical 235661. H. E., a man, aged 35, a native of Massachusetts, whose family and past history were unimportant, had been a foreman in a paper box factory for ten years, having come in contact with such materials as glazed paper, cardboard, much paper dust, dextrin, hoof glue and flour paste.

The present illness began one year ago when he noticed that his right hand was weak and that bowling balls slipped out of his fingers. His hands were slightly stiff and the palms a little sore. The soles of his feet were also somewhat sore; he was treated by his local doctor for fallen arches without receiving much relief. After about a month of these mild symptoms he felt comparatively well except for slight soreness of the palms and soles, Six months before entrance into the hospital he noticed that his symptoms were becoming gradually worse. The soreness and stiffness increased; his hands were frequently swollen in the mornings, and they perspired a great deal; at times they were painful on pressure or contact. On exposure to cold the fingers ached and became white or dusky. At present all of his joints are stiff after inactivity, but the fingers are constantly stiff in a position of slight flexion and are capable of little mobility. He had always slept well until about a month ago; since that time he has been restless at night and has slept poorly. He has lost about five pounds during the past year. For the past three months he has taken three pills daily, prescribed by his doctor for "rheumatism." There has been no soreness of the eyes, tongue or throat, and no gastro-intestinal disturbance.

Physical Examination.-This revealed typical sclerodermatous changes with diffuse brown pigmentation involving the hands, forearms, chest and abdomen; the palms were wet with perspiration. The only other positive findings were: a slightly irregular left pupil, enlarged epitrochlear and cervical lymph glands and systolic murmur at the cardiac apex transmitted to the axilla. The blood pressure was systolic 120 , diastolic 64 . Temperature and respirations were normal. The pulse rate varied between 68 and 85 . When seen five months later, there were no changes except for the presence of numerous small keratoses on the hacks of both hands.

Laboratory Examination.-The results of the laboratory examination were: urine, no albumin, sugar or sediment on two examinations; renal function, 45 per cent. phenolsulphonephthalein in two hours and ten minutes (normal). The blood smear was normal on two examinations. The white blood count was 8,400; hemoglobin (Talquist), 80. The routine stool examination was negative. The blood Wassermann reaction was negative. Blood uric acid was $4.1 \mathrm{mg}$. per 100 c.c. (high). Roentgen-ray examination of the hands and wrists was negative; it showed that the heart was slightly longer than normal. The basal metabolism was 10 (within normal limits). Analyses of the urine and stool for lead and of the stool for arsenic were negative; analysis of the urine for arsenic was positive. Analysis of specimens of four kinds of paper used in the factory, showed arsenic to be present in three-a rough finish gray paper, a tan paper, and a brown cardboard; no arsenic was found in a sample of white glazed paper.

CASE 2.-History--Skin 226621. L. R., a woman, aged 40, born in Russia, lived in Massachusetts for twenty-two years. Her family and past history were unimportant. For the past eight years she has kent a small grocery store 
in a damp hasement. For over four years it had been her habit to keep an open saticer filled with powlered arsenate of lead under her comnter for the purpose of killing mice.

The present illness hegan ahout four years ago with numbness, coldness. cyanosis and pallor of the finger tips of both hands. After persisting rather constantly for two years the fingers and hands gradually became stiff and brown. For the past two years there has been a constant aching pain in the hands and fingers, and the stiffness has progressed to practical fixation. During these four years she has heen troubled a great deal with pyrosis and ernctations without definite relation to meals. relieved somewhat by drinking milk but not by soda: there has been no natusea or romiting. She never had stomach trouble before her present illuess. She has lost 30 pounds in the past two years

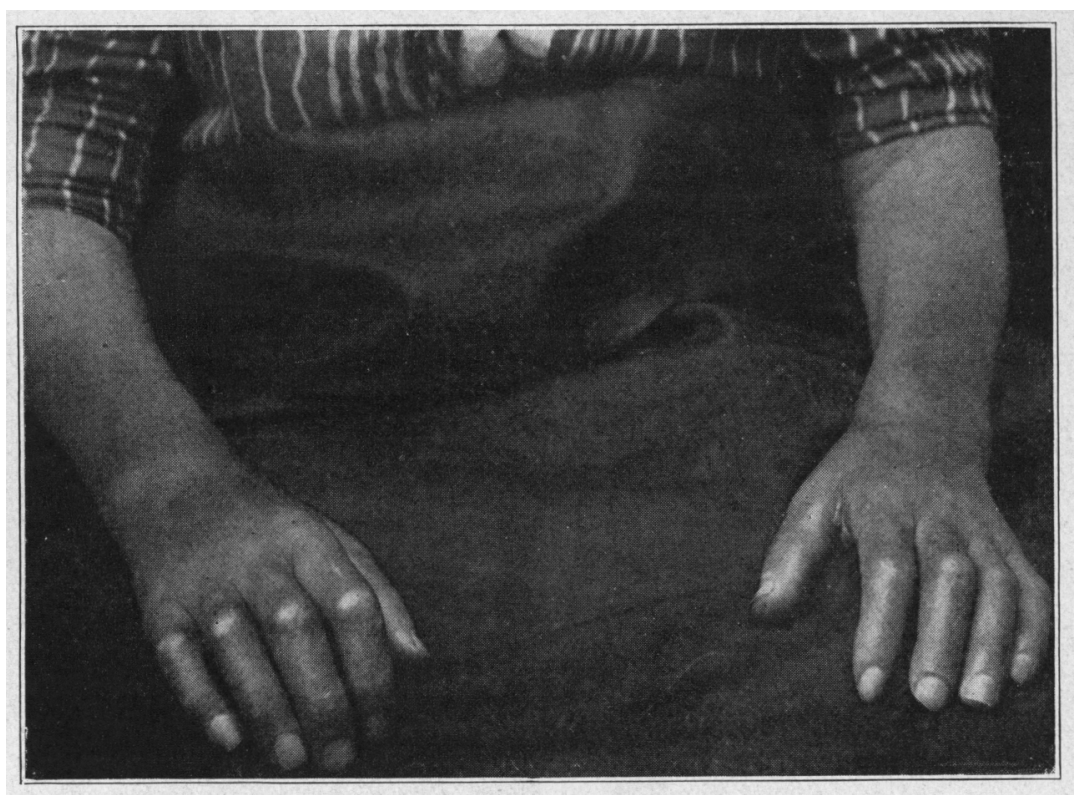

Case 2.-Typical sclerodactylia with pigmentation. infiltration and glossy skin. Similar changes involved face and neck. The same condition appeared in Cases 1 and 3. (Photograph hy Miss Harriet Williams.)

and fecls weak and tired all the time. Recently her catamenia has become slightly irregular and less frequent. Hoarseness has been progressive for many months.

Physical Examination. This was negative except for typical sclerodermatous changes with diffuse brown pigmentation involving hands, forearms and face. Over hoth elbows, where the skin seemed firmly attached to underlying structures, a coarse crepitation was heard and felt on motion. a phenomenon not noted elsewhere. Blood pressure was systolic 112. diastolic 70. Temperature, pulse and respiration were normal.

Laboratory Examination.-One routine urine examination was negative. The blood smear was normal. The white count was 14,000 (one estimation), hemoglobin 90 (Talquist). A Wassermann test and stool examination were not made. 
A barium roentgen-ray examination of the gastro-intestinal tract was negative. A urine test for arsenic showed that a considerable amount of arsenic was present.

CASE 3.-History.-East Medical 229709. L. R. S., a woman, aged 24, who had always been a resident of Massachusetts, had a negative family history. Her past history showed measles and mumps in childhood, peritonsillar abscess nine years ago which was incised, and pneumonia two years ago. Careful questioning failed to elicit any exposure to arsenic, except possibly through the use of insecticides about the house.

Her present illness began about twelve or thirteen years ago with swelling of the feet and ankles without redness, but with such tenderness that she was forced to give up her work in a shoe factory where she put laces into freshly lined shoes. Some weeks or months later her hands became numb, very brown and so stiff that she was unable to bend her fingers. About five years after the onset areas of brown pigmentation began to appear about the waist, neck, chest and in the joint flexures. About two weeks following pneumonia three years ago she had severe neuritis in both arms lasting several weeks. During the past year or more the numbness and stiffness of the fingers has diminished, and the legs, which several years ago were firm and hard, are now practically normal. She thinks she has lost some weight. She sleeps well. There has been no disturbances of digestion or of menstruation.

Physical Examination.-This revealed marked pyorrhea, bilateral tear of cervix, soft systolic cardiac murmur at apex, smooth and atrophic appearance of tongue on front and sides, dry and scant hair of scalp, axillae and pubes. The skin about the mouth was wrinkled and atrophic, and on the hands and forearms it was glossy, atrophic and firmly bound down. The pigmentation apparently had faded, but was still quite well marked on the hands, forearms, neck, chest, breasts, about the waist and mouth and in the axillae and cubital spaces; on the hands and arms there were areas of depigmentation. The fingers were in partial fixation. Blood pressure was systolic 140, diastolic 80. Temperature and respiration were normal. The pulse varied between 85 and 100 .

Laboratory Examination. - Routine urine examination was negative twice except that many white blood cells were present. Renal function was normal with 50 per cent. phenolsulphonephthalein in two hours and ten minutes. Roütine stool examination was negative. A Wassermann test was not made. The blood smear was normal; white count 7,000; hemoglobin 80. Blood nonprotein nitrogen was $32 \mathrm{mg}$. (normal); blood phosphates, $7.8 \mathrm{mg}$. (normal); blood carbon dioxid $34.5 \mathrm{~mm}$. of mercury (normal). Sugar tolerance test of the blood was normal. Urine test for arsenic was positive. The insecticide in use during the past year was negative for arsenic.

\section{ETIOLOGY}

The cause of scleroderma is unknown. ${ }^{1}$ A number of investigators " believe it is caused by functional or organic disturbances of the glands of internal secretion, especially the thyroid, asserting that a certain degree of improvement followed the feeding of thyroid substance.

1. Stelwagon, H. W.: Diseases of the Skin, Ed. 8, Philadelphia, W. B. Saunders Company.

2. Foerster, O. H.: J. Cutan. Dis. 34:1, 1916. 
Glandular pathology or dysfunction has not been a constant finding, and thyroid therapy has resulted in many disappointments. A basal metabolism of +10 in Case 1 , however, does not suggest either a thyroid deficiency or a hyperactivity as we understand it at present. A trophoneurosis is difficult to rule out. Vascular changes in the skin which frequently occur, sometimes progressing to occlusion, are probably secondary rather than causative. A review of the literature during the past twenty years and of all the available textbooks on dermatology has failed to reveal a single statement regarding scleroderma as a possible manifestation of chronic arsenic poisoning.

\section{ARSENIC IN THE URINE}

Arsenic may be found in the urine from three to nine months after exposure has ceased. The tests in the cases reported above were made by the Sanger method in the laboratory of Dr. W. Denis of this hospital. The estimations were purely qualitative.

It may be asked how many people, or at least people without arsenic poisoning, will show arsenic in the urine. J. J. Putnam, ${ }^{3}$ in 1890 , showed that arsenic was present in traces in twenty-one of forty-eight specimens of urine selected from patients in the outpatient department of this hospital who showed no symptoms referable to arsenic poisoning. He concluded from this that the discovery of arsenic in the urine cannot be taken as conclusive proof, or even as strong evidence, taken by itself, as to the origin of doubtful symptoms. On the other hand, "notwithstanding the diagnostic value of a urine analysis in suspected cases, it is not to be forgotten that a failure to find arsenic in this way is not a positive proof that it is not in the body, since, as Taylor and others have shown, arsenic may be excreted only intermittently by the kidneys, and even in acute fatal cases, the urine has been found free."

In this hospital records of chemical tests done on various body fluids and secretions have been kept during the last four and one-half years. Arsenic was recorded as present in twelve out of a total of twenty-five tests of the urine, and in these cases, unlike Putnam's series, the presence of arsenic was suspected as a cause for the symptoms in question.

Using these two series as controls, it is seen that arsenic was found in 43 per cent. of forty-eight specimens of urine selected at random, and in 48 per cent. of 25 specimens suspected of containing arsenic. If arsenic were found in a considerably higher percentage of a large series of specimens of urine from scleroderma patients, we would be justified in suspecting arsenic as an etiologic factor-pro-

3. Putnam, J. J.: Boston M. \& S. J. 122:421, 1890. 
vided we could show that the patients had not received arsenical medication in the treatment of their disease. As nearly as could be determined by direct questions and by examination of our records, none of the three patients in the cases reported had received arsenic as treatment for scleroderma, but obviously the possibility of having received it in medicine prior to coming under our observation could not be excluded.

\section{SOURCES OF ARSENIC POISONING}

About thirty or forty years ago there was an active interest in arsenic poisoning because of its rather frequent occurrence from the widespread and rather careless use of arsenic in various trades and articles of common use. At that time arsenical wall paper was a common source of danger. Public health legislation has no doubt offered considerable protection, yet the danger has not been entirely removed. The following is a list of articles and industries in which arsenic is or has been used: ${ }^{4}$ wall paper (red, orange, brown, gray, green); glazed paper and playing cards; rugs and carpets; printed or woven fabrics for use as garments, draperies, etc.; furs; artificial flowers and leaves; oil paint; lithographer's color printing; Venetian and other blinds; linoleum; japanned goods; book cloth and fancy bindings; tinted walls, bronzing, colored soaps, candy, wafers; children's toys, painted rubber dolls, rocking horses, hollow glass balls, etc.; wax ornaments for Christmas trees; anilin dyes; gloves, stockings, handkerchiefs and other articles colored by anilin; tanning hides or curing furs ; smelting lead and copper; shot making; scraping paint off ships ; tin plate works; galvanizing trades; electroplating; enameling ; manufacture of cut glass ; candles; artificial leather; hat linings; soaking of silk cocoons ; glucose ; beer ; medicines, Fowler's solution, etc.; “sheep dip" and other insecticides for spraying gardens ${ }^{5}$ or for household use.

One might ask how chronic arsenic poisoning could result from association with wall paper colored with arsenical dyes. B. Gosio ${ }^{6}$ and others have shown that at least seven species of molds are capable of producing a highly toxic gas, arsin, from minute amounts of arsenical compounds in their culture mediums. This principle is applied in one of the most delicate tests for arsenic, the biologic test. ${ }^{7}$ Penicil-

4. Proc. Med. Soc. London, 1880. Oliver, Thomas: Dangerous Trades, New York, E. P. Dutton \& Co., 1902, p. 378.

5. Ayres, Samuel, Jr.: Chronic Arsenic Poisoning on a Farm: Report of a Case, J. A. M. A. 71:2122 (Dec. 28) 1918.

6. Gosio, B.: Riv. d'ig. e san. pub., 1892, p. 201.

7. Autenreith and Warren: The Detection of Poisons and Powerful Drugs, Philadelphia, P. Blakiston's Son \& Co., 1915, p. 235. 
lium brevicaule, the most important in this group of molds, has been cultivated from the air. It grows readily on decaying paper, bread crumbs, and other substances.

People vary markedly in their idiosyncrasy to arsenic; some are poisoned readily, others are very resistant. Arsenical preparations vary in their toxicity, arsphenamin in reasonable amounts ordinarily being nontoxic, arsin gas highly poisonous, with many gradations between. According to Putnam, ${ }^{3}$ "there is nothing more striking in the clinical history of this matter than the fact that a person who once has been poisoned, or who is naturally susceptible, is sometimes affected by exposures that seem absurdly insignificant."

\section{SYMPTOMS}

Although localized scleroderma, morphea, may be symptomless except for the objective appearance, generalized scleroderma, of which the three cases reported are examples, nearly always presents constitutional disturbances of varying type and degree. Sir William Osler ${ }^{\text {s }}$ describes eight cases, some with severe constitutional symptoms. Herman Goodman ${ }^{9}$ reviews sixteen cases from the literature. There is a triad of symptoms which is almost invariably present both in diffuse scleroderma and in chronic arsenic poisoning: (1) neuritic manifestations, numbness, tingling, soreness: (2) pigmentation; (3) changes in the skin itself which, however, vary in the two diseases. The comparative symptomatology of the two diseases is given in the table.

A logical and reasonable question may be raised. If scleroderma is a manifestation of chronic arsenic poisoning, why has it never been described as occurring among arsenic workers, or in persons known to have arsenic poisoning? The following facts may account for a failure to connect the two processes: (1) the extreme rarity of both diseases, especially scleroderma; (2) inadequate history in regard to exposure to arsenic in cases of scleroderma; (3) owing to the fact that the average practitioner knows little or nothing of scleroderma, the disease no doubt is often unrecognized; (4) the possibility that scleroderma may be a specialized manifestation of chronic arsenic poisoning and occur independently of other symptoms, just as tabes dorsalis may occur without any concomitant skin lesions and even without the history of infection, and just as the gastro-intestinal symptoms may be the only evidence of pellagra, or lupus vulgaris the only evidence of tuberculous infection. As a matter of fact, in Osler's Case 8 , if the sclerodermatous changes could have been erased and a history of exposure to arsenic substituted, from his description of

8. Osler, W.: J. Cutan. Dis. 16:51, 1898.

9. Goodman, H.: J. Cutan. Dis. 38:210, 1918. 
Comparative Symptomatology of Diffuse Scleronerma and Chronic Arsenic Poisoning

\begin{tabular}{|c|c|c|}
\hline Symptoms & Diffuse Scleroderma & Chronic Arsenic Poisoning \\
\hline $\begin{array}{l}\text { Neuritic symp } \\
\text { toms }\end{array}$ & $\begin{array}{l}\text { Numbness, tingling, aching, sometimes } \\
\text { soreness and severe neuritic pains in } \\
\text { involved areas, frequent multiple } \\
\text { joint stiffness }\end{array}$ & $\begin{array}{l}\text { Similar symptoms; marked cutaneous } \\
\text { hyperesthesia }\end{array}$ \\
\hline Pigmentation & $\begin{array}{l}\text { Invariable, sooner or later; most } \\
\text { marked on selerodermatous areas; } \\
\text { may be diffuse. May be mottled } \\
\text { (Osler's Case } 8 \text { ) }\end{array}$ & $\begin{array}{l}\text { Common; diffuse or localized, espe- } \\
\text { cially on exposed parts or in folds } \\
\text { of joints; frequently mottled }\end{array}$ \\
\hline $\begin{array}{l}\text { Cutaneous } \\
\text { changes }\end{array}$ & $\begin{array}{l}\text { Sometimes erythema and edema early } \\
\text { (edema of eyelids, Osler's Case 6); } \\
\text { later skin becomes hard, bound } \\
\text { down, glossy; sometimes ulceration; } \\
\text { roughness of nails, loss of hair, } \\
\text { hyperhidrosis of palms and soles; } \\
\text { keratoses, author's Case } 1\end{array}$ & $\begin{array}{l}\text { Sometimes erythema, frequently kera- } \\
\text { tosis, diffuse or localized to palms } \\
\text { and soles, sometimes with desquama- } \\
\text { tion; sometimes papules, pustules, } \\
\text { vesicles, or bullae; frequently edema } \\
\text { of eyelids, roughness of nails, loss } \\
\text { of hair; hyperhidrosis of palms and } \\
\text { soles }\end{array}$ \\
\hline I.oss of weighl & Usually marked $\ldots \ldots \ldots \ldots \ldots \ldots \ldots$ & Present \\
\hline $\begin{array}{l}\text { Areas of in- } \\
\text { volvement }\end{array}$ & Frequently extremities and face...... & $\begin{array}{l}\text { Motor and sensory symptoms alike } \\
\text { affect prineipally the distal portions } \\
\text { of extremities, rarely extending } \\
\text { above elbows and knees; face fre- } \\
\text { quently involved }\end{array}$ \\
\hline $\begin{array}{l}\text { Gastro- } \\
\text { intestinal }\end{array}$ & $\begin{array}{l}\text { Sometimes pyrosis, constipation. diar- } \\
\text { rhea, vomiting, abdominal cramps } \\
\text { (Osler's Cases } 1,3 \text { and 8); may be } \\
\text { no symptoms }\end{array}$ & Same symptoms are common \\
\hline Fever & $\begin{array}{l}\text { Not constant; there may be several- } \\
\text { degrees during active progression of } \\
\text { disease or at death }\end{array}$ & At times slight irregular fever \\
\hline Onset & $\begin{array}{l}\text { Frequently with numbness and ting- } \\
\text { ling of hands and feet; sometimes } \\
\text { with stifiness of joints; occasionaly } \\
\text { with symptoms of Raynaud's dis- } \\
\text { ease }\end{array}$ & $\begin{array}{l}\text { Frequently with gastralgia or with } \\
\text { numbness or tingling of hands and } \\
\text { feet }\end{array}$ \\
\hline $\begin{array}{l}\text { Vasomotor } \\
\text { disturbances }\end{array}$ & $\begin{array}{l}\text { Usually present, especially in fingers: } \\
\text { vasomotor paresis in Osler's Case } 7\end{array}$ & Common \\
\hline Heart & $\begin{array}{l}\text { Occasionally irregular or rapid (Os- } \\
\text { ler's Case 7) }\end{array}$ & Occasionally irregular \\
\hline Eyes & Not usually affected................. & Frequent conjunctivitis \\
\hline $\begin{array}{l}\text { Muscular } \\
\text { weakness }\end{array}$ & $\begin{array}{l}\text { Frequently present as in our Case } 2 \\
\text { and Osler's Case } t\end{array}$ & Ususally present \\
\hline Headache & Not usually complained of $\ldots \ldots \ldots \ldots$ & Common \\
\hline $\begin{array}{l}\text { Mouth and } \\
\text { throat }\end{array}$ & $\begin{array}{l}\text { Disease sometimes begins with an at- } \\
\text { tack of sore throat; occasionally } \\
\text { hoarseness is present }\end{array}$ & $\begin{array}{l}\text { Frequent sore tongue and mouth; oc- } \\
\text { casional hoarseness and bronchitis, } \\
\text { coryza, cough }\end{array}$ \\
\hline Salivation & Not recorded $\ldots \ldots \ldots \ldots \ldots \ldots \ldots \ldots \ldots$ & Frequent; marked thirst \\
\hline Anemia & Oecusional $\ldots \ldots \ldots \ldots \ldots \ldots \ldots \ldots \ldots \ldots \ldots \ldots \ldots \ldots$ & Occasional \\
\hline Menstruation & Occasionally irregular $\ldots \ldots \ldots \ldots \ldots \ldots$ & Occasionally irregular \\
\hline Paralysis & Not recorded; disability from flxation & Occasional \\
\hline Sudden death & Oceasional (Osler's Case 7 ).......... & Not recorded \\
\hline
\end{tabular}


the case, we should have had a fair picture of chronic arsenic poisoning: weakness, marked loss of weight and appetite, gastro-intestinal disturbances, an intense bronze pigmentation, mottled in character, involving chiefly the face, thorax, abdomen and thighs.

Putnam ${ }^{10}$ says that "lead, arsenic, and similar poisons, do not always accumulate in the same organ of the body . . . but the position of greater accumulation varies according to the rapidity of absorption (solubility) of the special preparation ingested, the rap:dity of elimination and similar factors." At the first opportunity a chemical examination should be made of sclerodermatous tissue at necropsy to determine the presence or absence of arsenic.

Concerning pigmentation in scleroderma, Osler ${ }^{11}$ remarks that "there may be the muddy brown discoloration which is common in atrophic areas, or there may be a curious mottled or freckled appearance such as we so often see in the arsenical pigmentation about the abdomen. But the most remarkable instances are those in which the entire skin becomes of a deep brownish black like the most extreme form of Addison's disease." He adds that there are frequently accompanying areas of leukoderma.

\section{PATHOLOGY AND TREATMENT}

I shall not go into detail on these subjects; as they are adequately dealt with in numerous textbooks. Dinkler ${ }^{12}$ and La Grange ${ }^{13}$ have shown that nerve centers, peripheral nerves, heart and large vessels are free from pathologic changes. Unna ${ }^{14}$ points out that hypertrophy of preexisting collagenous bundles is the main process, and that whatever vascular occlusion occurs is secondary to this, otherwise "we would see at a certain stage, sclerotic vessels running in normal cutaneous tissue, which we do not;" atrophy of muscles and bones, atrophy or hypertrophy of the thyroid, and atrophy of the suprarenal gland, are some of the rather inconstant necropsy findings. ${ }^{1}$

No successful treatment has been found. In some cases the disease undergoes spontaneous involution, in other cases it becomes arrested, and in others death occurs suddenly or after a prolonged and incapacitating illness. Massage and baking are palliative. Quartz light therapy is a suggestion.

10. Putnam, J. J.: Boston M. \& S. J. 119:2, 1888.

11. Osler and McCrae: Modern Medicine 4: 1915.

12. Dinkler: Scleroderma, Heidelberg, 1891.

13. Lagrange: Contribution to the Study of Scleroderma with Arthropathia, Thesis, Paris, 1874.

14. Unna: The Histopathology of the Disease of the Skin, New York, Macmillan Co., 1896, p. 1110. 


\section{SUMMARY}

1. Three consecutive patients with diffuse scleroderma at the Massachusetts General Hospital showed arsenic in the urine, and two of them gave a history of exposure to arsenic. One patient with morphea frontalis had been exposed to arsenic and showed arsenic in the urine.

2. The possibility of scleroderma being a manifestation of chronic arsenic poisoning cannot be affirmed from the evidence at hand.

3. Careful histories as to the possible exposure to arsenic, a detailed record of general symptomatology and arsenic tests of the urine of a large series of cases of scleroderma would tend to determine whether arsenic plays a rôle in the etiology of scleroderma.

4. Arsenic has been found in traces in 43 per cent. of a series of forty-eight specimens of urine selected at random. It would have to be present in a much higher percentage in urine from sclerodermatous patients to be of any significance.

5. Scleroderma and chronic arsenic poisoning possess many symptoms in common in individual cases, such as neurit:c manifestations, pigmentation, cutaneous alterations of various kinds, loss of weight with muscular weakness, intermittent irregular fever, gastro-in estinal disturbances, vasomotor instability, rapid and irregular heart, menstrual disturbances, etc. On the other hand, many of these symptoms may be lacking in cases of well advanced scleroderma. ${ }^{15}$

I wish to thank Dr. William H. Smith of the West Medical Service, Dr. David L. Edsall of the East Medical Service, and Dr. Harvey P. Towle of the Dermatological Service for reviewing and criticizing this paper. I also wish to thank Dr. William H. Smith and Dr. E. Lawrence Oliver for permission to report Case 1, in which the patient was a private patient.

820 Baker-Detwiler Building.

15. In addition to the references already given, the following may be of interest :

Brooke, H. G., and Roberts, Leslie: The Action of Aresenic on the Skin as Observed in the Recent Epidemic of Arsenical Beer Poisoning. Brit. J. Derm. 13:121, 1901. 